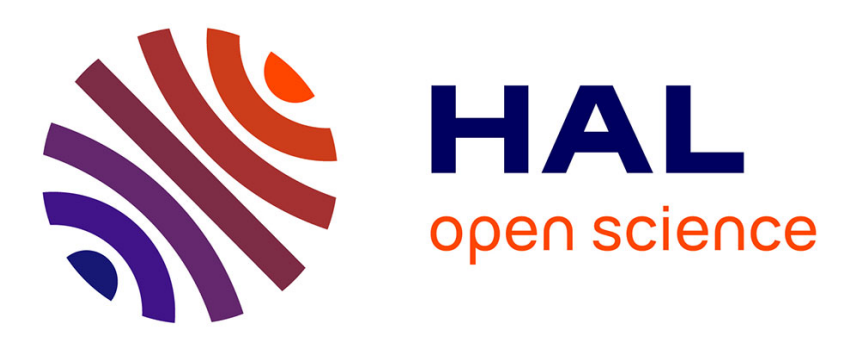

\title{
Territorial or wandering: how males of Protodiscelis palpalis (Colletidae, Paracolletinae) behave in searching for mates
}

Reisla Oliveira, Airton Carvalho, Clemens Schlindwein

\section{- To cite this version:}

Reisla Oliveira, Airton Carvalho, Clemens Schlindwein. Territorial or wandering: how males of Protodiscelis palpalis (Colletidae, Paracolletinae) behave in searching for mates. Apidologie, 2012, 43 (6), pp.674-684. 10.1007/s13592-012-0142-0 . hal-01003664

\section{HAL Id: hal-01003664 https://hal.science/hal-01003664}

Submitted on 1 Jan 2012

HAL is a multi-disciplinary open access archive for the deposit and dissemination of scientific research documents, whether they are published or not. The documents may come from teaching and research institutions in France or abroad, or from public or private research centers.
L'archive ouverte pluridisciplinaire HAL, est destinée au dépôt et à la diffusion de documents scientifiques de niveau recherche, publiés ou non, émanant des établissements d'enseignement et de recherche français ou étrangers, des laboratoires publics ou privés. 


\title{
Territorial or wandering: how males of Protodiscelis palpalis (Colletidae, Paracolletinae) behave in searching for mates
}

\author{
Reisla Oliveira $^{1,2}$, Airton Torres CARVAlHo ${ }^{1}$, Clemens Schlindwein $^{3}$ \\ ${ }^{1}$ Programa de Pós-Graduação em Ciências Biológicas-Zoologia, Universidade Federal da Paraíba, Cidade \\ Universitária, 58059-900 João Pessoa, Brazil \\ ${ }^{2}$ Departamento de Biodiversidade, Evolução e Meio Ambiente, Universidade Federal e Ouro Preto, Campus Morro \\ do Cruzeiro, 35400-000 Ouro Preto, Brazil \\ ${ }^{3}$ Departamento de Botânica, Universidade Federal de Minas Gerais, Av. Antônio Carlos, 6627, 31270-110 Belo \\ Horizonte, Brazil
}

Received 19 September 2011 - Revised 27 April 2012 - Accepted 10 May 2012

\begin{abstract}
Females of Protodiscelis palpalis are oligolectic on flowers of the aquatic herb Hydrocleys martii (Limnocharitaceae), commonly found in Northeast Brazil. Each morning, $1 \mathrm{~h}$ before anthesis, males fight to guard small patches of flowers, which will compose their territories. Non-territorial males are not bound to certain areas on their patrol flights, roam between different territories and do not engage in conflicts with conspecific males. Territorial males aggressively defend flowers only in a restricted, intensely patrolled part of the territory. This core area was never shared with other territorial males. The intensive patrolling of a territory sector may be a response to abundant territorial invasions by conspecific males. Being territorial seems to confer reproductive advantages to the males. However, the severe male competition and the extreme spatiotemporal aggregation of resource flowers observed in the temporary water bodies of the Caatinga obscure which mating strategy provides higher male reproductive success.
\end{abstract}

\section{territoriality / mating strategy / oligolecty / solitary bees / Caatinga}

\section{INTRODUCTION}

Males of solitary bees typically allocate most of their energy to find receptive females and mate, while females do on parental care. Females usually represent the limiting sex and exert a selective pressure on the male's phenotypic traits, which should increase their chances to find and fertilize a female (Thornhill and Alcock 1983).

Spatial and temporal patterns of resource distribution can affect the spatial distribution of females, which consequently affects the possible

Corresponding author: R. Oliveira, reisla_oliveira@yahoo.com.br Manuscript editor: Stan Schneider mating sites and mating strategies of males (Emlen and Oring 1977; Paxton 2005). In searching for females, males use three types of mating sites: (1) non-resource sites, i.e. sites not related to nests or food resources like in several Xylocopini (e.g. Alcock 1996; Leys 2000); (2) nesting sites, like in Centridini and Tapinotaspidini (Alcock et al. 1976; Hiller and Wittmann 1994; Cunha and Blochtein 2003) and (3) flowers, as in Anthidiini, Centridini, Emphorini, Megachilini, Osmiini and Xylocopini, among others (Raw 1976; Eickwort and Ginsberg 1980; Roubik 1989; Alves dos Santos 2000; Medeiros and Schlindwein 2003; Oliveira and Schlindwein 2010). While patrolling flowers, males may either search for females without being engaged in combats with conspe- 
cific males or may actively defend flowers in order to restrict other males in accessing floral resources. Males of the same population can also search for females at different sites using alternative mate-locating strategies (eg. Alcock et al. 1977b; Danforth 1991; Alcock 1997; Oliveira and Schlindwein 2010).

In oligolectic species, females specialize in using pollen exclusively from a single genus or plant family (Robertson 1925; Cane and Sipes 2006). This provides males higher predictability of the locations where females forage. In Brazil, until now about 70 bee species are known to be oligolectic, and in at least half of them, males patrol the specific resource flowers while searching for females (Schlindwein 2004). Nevertheless, the mating systems are known for only four species (Wittmann et al. 1990; Medeiros and Schlindwein 2003; Milet-Pinheiro et al. 2008; Oliveira and Schlindwein 2010).

The subfamily Paracolletinae (Colletidae) includes about 400 species, distributed in South America, Australia and New Zealand (Silveira et al. 2002; Michener 2007; Almeida and Danforth 2009). All neotropical species seem to be oligolectic (Schlindwein 2004) and, as for the rest of the tribe, of unknown mating system. Protodiscelis palpalis (Ducke, 1909) is one of the few paracolletine species occurring in the tropical part of Brazil (Silveira et al. 2002). Females of this species are narrowly oligolectic on flowers of Hydrocleys (Limnocharitaceae), aquatic plants which are the exclusive source of pollen for larvae (Carvalho and Schlindwein 2011). Patches of $H$. martii Seub. cover the surface of ponds and ephemeral water bodies, which are islands of food resource for these bees in the Caatinga dry forest in Northeastern Brazil. Both the narrow oligolecty of females and the aggregated distribution of their pollen source should favour resource-defence as male mating strategy in this bee.

In the present work, we describe the reproductive behaviour of $P$. palpalis, and observed two alternative mating strategies: territorial defence of flower clumps, and patrolling. We quantify the cost and benefits of the strategies in terms of encounters with females and mating success.

\section{MATERIAL AND METHODS}

\subsection{Study site}

We studied the behaviour of $P$. palpalis bees of a population in the Estação Ecológica do Seridó (ESEC-Seridó- $06^{\circ} 35^{\prime} \mathrm{S}$ and $37^{\circ} 20^{\prime} \mathrm{W}$ ), between May and July 2006 and 2007, which is the flight season of the bees. The Nature Reserve covers an area of 1,166 ha of Caatinga, a tropical dry forest characterized by xerophytic shrubs and trees, abundant succulents with an herbaceous layer only in the rainy season (Andrade-Lima 1961; Duque 1973). The climate is dry, with extremely irregular rainfall, resulting in an annual precipitation oscillating between 300 and 1,000 mm (Sampaio 1995).

\subsection{Hydrocleys martii}

H. martii is an ephemeral aquatic herb, restricted to temporary ponds, growing in shallow depressions during the rainy season. The longevity of these water bodies depends on the amount of rainfall, which varies strongly from year to year. In most ponds, $H$. martii covers most of the water surface (Carvalho and Schlindwein 2011). The yellow flowers are cupshaped and show a central staminode cone that covers numerous fertile stamens and four apocarpous carpels. Flowers open simultaneously around 9:00 h and close between 13:00 and 14:00 h. Flower buds emerge from the water surface in the afternoon before anthesis and closed flowers submerge again a few hours after wilting. Individuals of Protodiscelis martii search the flowers looking for nectar and pollen. They are the sole effective pollinators and by far the most abundant flower visitors (Carvalho and Schlindwein 2011).

\subsection{Male mating tactics}

Activities of females and males were recorded between 08:00 and 12:00 h. Males were captured with entomological nets and marked on the mesoscutum and/ or metasomal terga with individual codes of colours. Edding pens 751 and 780 (Edding International $\mathrm{GmbH}$, Ahrensburg, Germany) or Revell colours (Revell GmbH \& Co. KG, Bünde, Nordrhein-Westfalen, Germany) were used for marking. The activities of re- 
sighted patrolling males and their interactions with females or conspecific males were recorded orally using a voice recorder. In addition, we made video recordings with a digital Camcorder (Sony).

Males that were observed for at least 1 day patrolling a specific area with $H$. martii flowers, showing aggressive behaviour against con-specific males, were classified as territorial. Chases, bites and touches in flight were considered agonistic behaviours. Territorial males were easily recognized because they were continually engaged in conflicts with conspecific males and in the custody of the sole resource flowers of females. Wandering males, on the other hand, roam over the territories, and do not display aggression against conspecific males.

The boundaries of the territories were defined with pieces of cord. To characterize the territorial behaviour, we followed 10 marked males, and for each territorial male, during $1 \mathrm{~h}$ we recorded the number of patrolled flowers, interactions with females and wandering males, and the number of copulation attempts by territorial and wandering males, invading the territory. From the copulation attempts, we recorded how many were successful, to obtain an estimate of the rate of copulations for each strategy. To verify if non-territorial males opportunistically inspect flowers in territories and compete for the possession of flowers, we counted the number of territory invasions in the absence of the resident territory owner. This was repeated 60 times in 10 territories.

\subsection{Female sexual attractiveness}

To verify whether mated females are still sexually attractive, 20 freshly mated females were captured: 10 were exposed in patrol routes of different males $30 \mathrm{~min}$ after copulation and 10 one day after mating. We tied up the females at the corolla using a thread between the meso- and metasoma. Females were placed in a way that they could take up nectar while being attached to the flowers. We observed each female for $10 \mathrm{~min}$, recording the number of touches, mounts and copulations they elicited.

\subsection{Statistical analyses}

Spearman rank correlation $\left(r_{\mathrm{s}}\right)$ was used to check for the relationship between number of flowers in a territory and the copulation rate (number of copulations/ number of attempts), encounters with females and contests with intruders. The difference between the copulation rates of territorial males and wandering males in the same territory was tested using Wilcoxon test for paired samples. The numbers of flowers contained in the core area and the total area of a territory was compared using chi-square. We used Statistica version 6.0 (Tulsa, USA) for data analysing. Mean values are followed by \pm standard error.

\section{RESULTS}

Males of $P$. palpalis employed alternative strategies in searching for partners. Some of them patrolled and defended aggressively patches of $H$. martii flowers, restricting the access to the flower for con-specifics males. Territorial males maintained the patrol area throughout anthesis, while wandering males followed the tactic to patrol flowers in search of receptive females without occupying a specific patrol area or showing aggression against other males.

\subsection{Establishing a territory}

The first males reached the flowers at 08:00 am, about $1 \mathrm{~h}$ before the anthesis of the H. martii flowers. They hovered over and touched flower buds until the flowers allowed access to the staminode cone. With the first landings of males on the staminodes of recently opened flowers, a series of escalating contests between males occurred. The duels involved touches, bites, grasping, chases in flight and some fighting couples even fell down to Hydrocleys leaves and the water surface. This period of intense conflicts lasted for 5 to $15 \mathrm{~min}$ $(N=15)$ until one male remained alone inside the still opening new flower, looking outward. When the first females arrived at the flowers around 9:00 $\mathrm{h}$, the territories were already established. The possession and distribution of the territories was defined daily, always after combats between males and before the arrival of females $(N=10)$. 


\subsection{How males search for mates}

Territorial males inspected 18 to 78 flowers of $H$. martii $(N=10, X=49 \pm 6.84)$ for the entire period of anthesis. Although all flowers in the patrolled area were regularly inspected in search for receptive females, only 10 to 26 flowers ( $N=10, X=16 \pm 1.58$ ) were defended when being inspected by rivals. In addition to this sector of the territory, hereafter core area, males patrolled further eight to 63 flowers ( $N=10, X=35 \pm 6.32$ ) without showing aggression. On average, for each inspection in the whole territory, there were 2.5 patrol flights in the core area. Although we did not record sharing of flowers among territorial males in the core area, in the rest of the territory up to 15 flowers $(N=6 \pm 1.3$ flowers) were co-patrolled by males from neighbouring territories. We distinguished the core area from the rest of the territory by the greater intensity of inspections and aggressive behaviour by the resident male in this area (Table I). For the 10 territorial males, there was a wide variation in the total number of flowers contained in the entire territory $(N=10$; variance $=$ 467.57), but the number of flowers inspected within the core area was rather constant among the territories $(N=10$; variance $=25.11)$.

We recorded between two and 85 expulsions of rivals from the core area per hour (average $29 \pm 8.17)$ and, on average, $1.98 \pm 1.14$ wandering males ( $N=296$ invasions) invading a territory concomitantly. In these interactions, the territorial males briefly chased the intruder males in flight, sometimes touching them. Wandering males were expelled from the territory while taking up nectar, inspecting flowers or attempting to copulate with foraging females. From 168 observed invasions of a territory, about $60 \%$ were by two or more non-resident males concomitant (number of invaders $=1-5$ ). Males that expelled more intruders from their territory per hour mated less frequently (Spearman correlation $r_{\mathrm{S}}=-0.69, N=10, P=0.04$; Figure 1). Territorial males were absent from their territory from $1 \mathrm{~s}$ to $3 \mathrm{~min}$. At $76 \%$ of the absences, flowers in the territory were invaded by rivals (726 absences, 11 territories).

Wandering males were sighted irregularly in the same area inspecting flowers. They never confronted other males, except when they attempted to mate or faced a copulating pair. During the grasping of partners, we observed up to four males fighting for gathering a receptive female.

Territorial males were successful in mating in $39 \%$ of their copulation attempts $(3.10 \pm 2.08$ copulations at $7.8 \pm 4.2$ attempts per hour), and wandering males in $24 \%$ of observed attempts ( $1.56 \pm 1.58$ copulations at $6.44 \pm 4.30$ attempts). A territorial male, on average, had the same success in copulations per hour as the sum of all invaders of their territory (Wilcoxon paired samples: $Z=1.007, N=10, P=0.314$; Figure 2). Since wandering males could not been individually marked and followed, it was not possible to determine their copulating rates per hour.

Males with larger territories did not copulate more often than those with territories that contained fewer flowers. There was also no relationship between the number of flowers in a territory and the number of expulsions per territory (Table II).

\subsection{Attractiveness of females}

Males attempted to mate with only one of the 10 available females $30 \mathrm{~min}$ after copulation,

Table I. Territory characteristics of males of Protodiscelis palpalis, of the core areas and the remaining territories $(N=10)$.

Sector of the territory No. of flowers $(X \pm \mathrm{SD})$

No. of shared flowers with territorial males
No. of flower inspections

in the sector per patrol circuit 


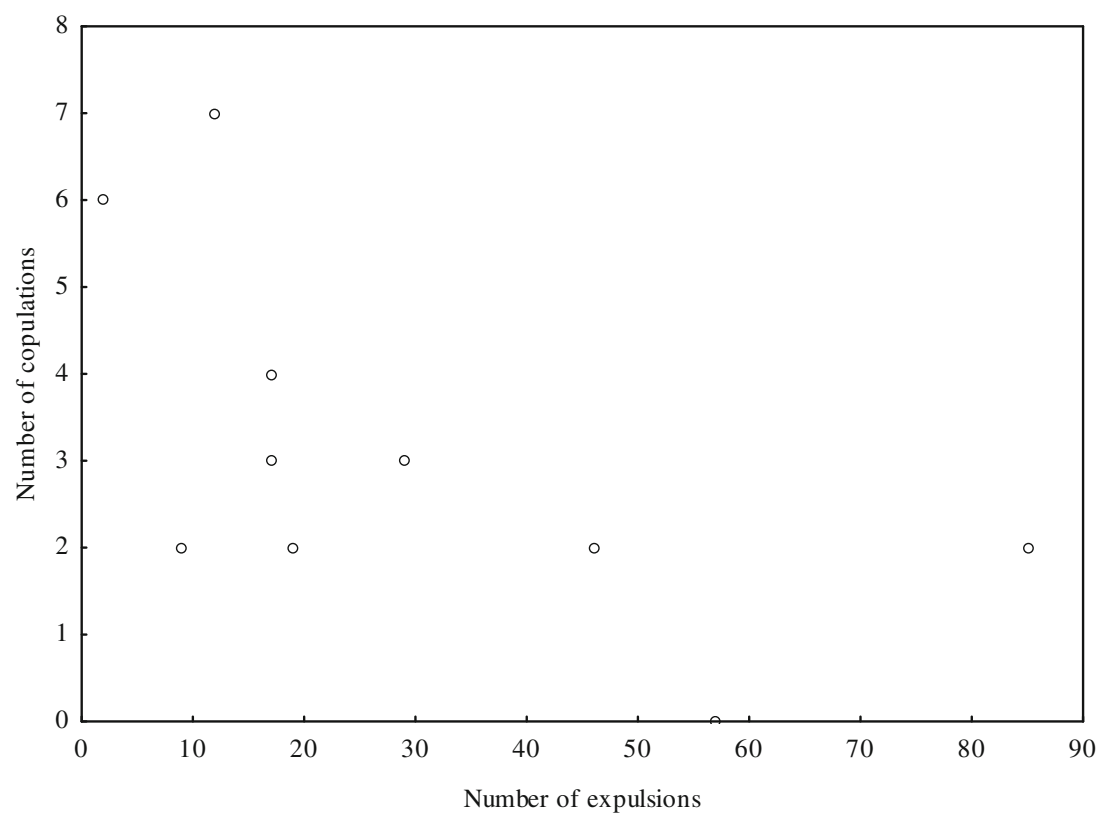

Figure 1. Relationship between the number of expulsions of intruder males by the territory owner per hour in $P$. palpalis and the number of copulations made in this period.

and with four out of 10 one-day-mated females (Figure 3). Females presented 1 day after copulation were touched more frequently by males than females that had copulated 30 min before presen- tation to males (Mann-Whitney $U$ test: $U=20$, $\left.N_{1}=N_{2}=10, P=0.023\right)$. However, there was no statistical difference in the number of copulations among both $\left(U=35, N_{1}=N_{2}=10, P=0.13\right)$.

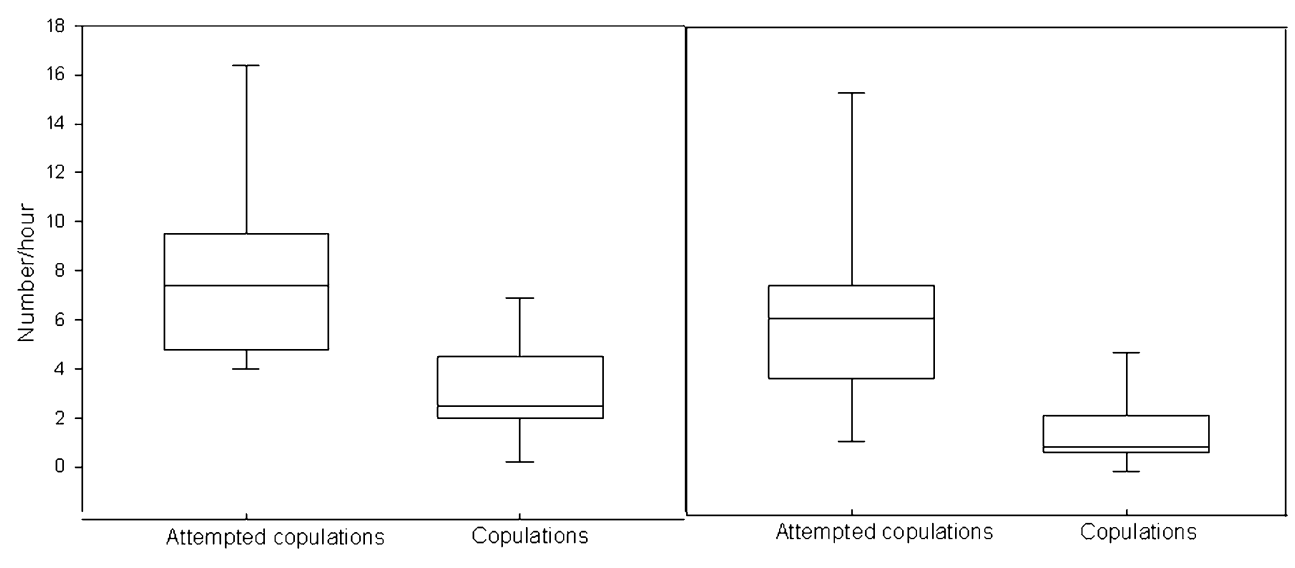

Figure 2. Number of attempted and successful copulations by territorial and wandering males at flowers of $H$. martii. A territorial male copulated as much as the sum of wandering males that invaded its territory $(N=11, Z=$ 1.610, $P=0.1073$ ). Box plots indicate the first and third percentiles (boxes), median (line in box) and minimum and maximum values (whiskers). 
Table II. Relationship between the number of flowers in the core area and whole area of a territory and mating success of territorial and wandering males of Protodiscelis palpalis and the number of expulsions of males per territory.

\begin{tabular}{|c|c|c|c|c|}
\hline \multirow[b]{3}{*}{ Tested variables } & \multicolumn{4}{|c|}{ No. of flowers } \\
\hline & \multicolumn{2}{|c|}{ Core area } & \multicolumn{2}{|c|}{ Total } \\
\hline & $r_{\mathrm{S}}$ & $P$ & $r_{\mathrm{S}}$ & $P$ \\
\hline Copulation rate/territorial males & -0.42 & 0.27 & 0.27 & 0.48 \\
\hline Copulation rate/wandering males & 0.24 & 0.53 & 0.13 & 0.75 \\
\hline Expulsions of males & 0.08 & 0.84 & 0.03 & 0.95 \\
\hline
\end{tabular}

\section{DISCUSSION}

Two alternative mating strategies were found for $P$. palpalis: territorial defence of clumps of flowers and wandering among these territories. Non-territorial males are often called satellite male (e.g. O’Neill 1983; Convey 1989; Hugie and Lank 1997; Brockmann 2001). However, this term is not clearly defined in literature and alternative denominations like sneakers (e.g. Simmons et al. 2000; Aubin-Horth and Dodson 2004), subordinates (e.g. Alcock 1979; Franck et al. 2003), floaters (e.g. Butchart et al. 1999; Adams 2001) and also wanderers (e.g. Utzed and Dell'anna 1989; Murai 1992; Jennions and
Backwell 1996; Milner et al. 2010) have been used. In all cases these terms refer to nonterritorial males, but not necessarily these males show the same mating behaviour. We opted to call them wandering males, as a type of satellite males. A review of these terms and definitions is desirable.

Males compete intensely for territories, which are defined daily in aggressive contests $1 \mathrm{~h}$ before flower opening and arrival of the females. Even those males who have secured the possession of a flower patch of $H$. martii on the previous day, needed to establish a new territory and maintain the territorial status the day after. None of the individually marked males was

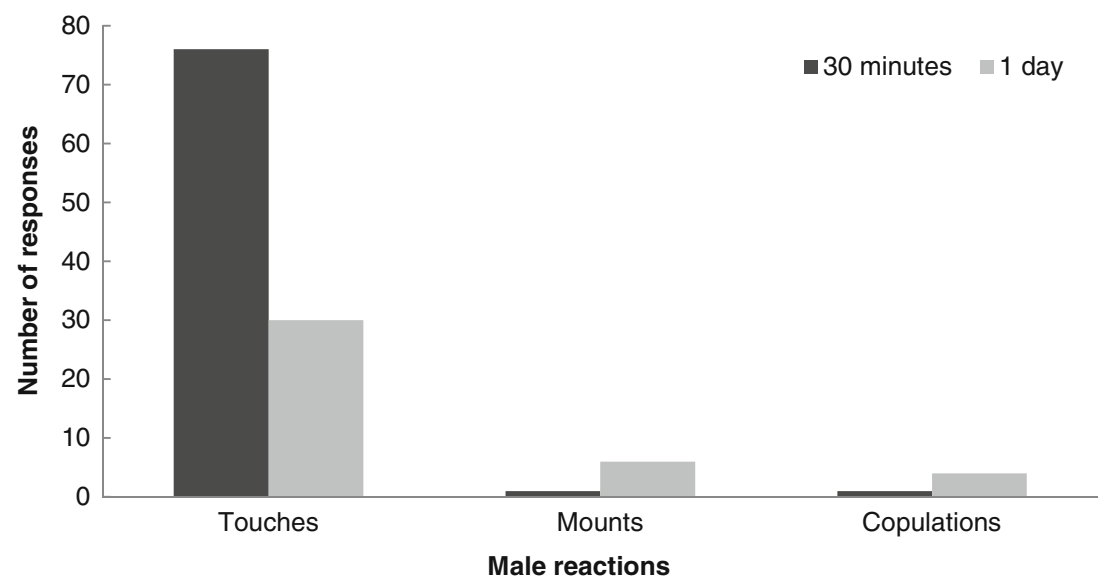

Figure 3. Responses of males to females of $P$. palpalis presented in flowers of $H$. martii within territories 30 min after mating and 1 day after mating ( $N=10$ per test). Numbers of touches, mounts and copulations were counted during $10 \mathrm{~min}$. 
observed occupying the same area on the following day. This recurring struggle for territories is in contrast to what happens in many other solitary bees, such as Ptilothrix fructifera (Apidae), Ceblurgus longipalpis (Halictidae), Protomeliturga turnera (Andrenidae) and Anthidium maculosum (Megachilidae), where males maintain territories in flowers for up to five, six, 14 and 21 days, respectively (Alcock et al. 1977a; Medeiros and Schlindwein 2003; Pinheiro et al. 2008; Oliveira and Schlindwein 2010).

\subsection{Why the tenacity of the territories is low in $P$. palpalis?}

There are two non-exclusive reasons for these daily recurrent struggles for territories between the males: (1) there are daily variation of the spatial distribution of flowers of $H$. martii. At the end of each day, flowers submerge, and new buds emerge each morning, changing the spatial configuration of flowers that makes the maintenance of the territories difficult. The dynamics of flowering of $H$. martii also makes the flowers unavailable as dormitory site for a resident male. At the end of anthesis, males should not only leave their territory, but the patrolled water body. Shortly before the beginning of anthesis, males have to re-orientate themselves to the new available flowers to compete for the possession of a new territory. (2) The high rate of invasions of the territories indicates a high competition for possession of flowers, a key resource to females. Eickwort and Ginsberg (1980) suggested that the tenacity of a territory is inversely related to the level of intraspecific competition of males. Territorial males of Hoplites anthocopoides (Megachilidae), for example, maintain the same territory for 2 days at the beginning of the breeding season and for 16 days at the end of the flowering of Echium vulgare (Boraginaceae), when the density of con-specific males at the only larval pollen sources for this species is lower (Eickwort 1977). The low tenacity of territories or abandonment of territorial behaviour in response to high rates of aggression was also seen in wasps (Evans and O'Neill 1978), flies (Borgia 1980), tarantula hawk wasps
(Alcock 2000) and butterflies (Rutowski 1991). Because it was not possible to follow the same marked males throughout the entire flowering season of $H$. martii, our results indicate a high turnover of territorial males at the same patrol area, but we have no information about changes of the status between territorial and wandering among males in the same water body. Thus, although it is clear that males of $P$. palpalis change their patrol area each day, it is still not clear whether non-territorial males can switch to territorial behaviour or vice-versa.

\subsection{Core areas: mitigating the costs of territoriality?}

Throughout the anthesis, territorial males incessantly inspected the flowers present in their area of patrol. However, they did not invest the same time in all sectors of the territory. The flowers of the core were inspected two to three times more often than those in the remaining territory. Males should reduce the costs of territoriality by reducing the number of flowers intensely defended and avoiding areas heavily defended by rivals. Our results show that involvement in contests with a conspecific male reduces territorial male's chances of mating (Figure 3). The number of flowers a male defends in the core area is probably one of the critical features in the trade-off of territory maintenance. This may explain why the number of flowers in the core area was relatively homogeneous among males, while the variance of the number of flowers outside the core was 18 times higher than in the core. Similarly, more intense defence of high-quality areas in territories has been observed in males of Aegelenopsis spiders (Riechert 1979) and of the brown anoles Anolis sagrei (Calsbeek and Marnocha 2006).

We did not find a positive relationship between the number of guarded flowers and the number of encounters with females in any sector of the territory. Since patches of $H$. martii covered the whole surface of water bodies, the limits of territories, when not chemically defined, could be imperceptible to foraging females. At high rates of conflict between conspecific males, to 
Table III. Examples of solitary, oligolectic bee species in which mating systems involve resource defence.

\begin{tabular}{|c|c|c|c|}
\hline Oligolectic bee species & Pollen plant/mating sites & References & $\begin{array}{l}\text { Aggregated } \\
\text { nests }\end{array}$ \\
\hline \multicolumn{4}{|l|}{ APIDAE } \\
\hline Epicharis metatarsalis & $\begin{array}{l}\text { Apeiba membranacea } \\
\text { (Tiliaceae) }\end{array}$ & Thiele and Inouye 2007 & $\mathrm{Yes}^{\mathrm{a}}$ \\
\hline Ptilothrix fructifera & Opuntia (Cactaceae) & $\begin{array}{l}\text { Oliveira and } \\
\text { Schlindwein } 2010\end{array}$ & Yes \\
\hline \multicolumn{4}{|l|}{ ANDRENIDAE } \\
\hline Anthrenoides micans & Parodia (Cactaceae) & $\begin{array}{l}\text { Oliveira and Schlindwein } \\
\text { (unpubl data) }\end{array}$ & $?$ \\
\hline Protomeliturga turnerae & $\begin{array}{l}\text { Turnera subulata } \\
\text { (Turneraceae) }\end{array}$ & $\begin{array}{l}\text { Medeiros and } \\
\text { Schlindwein } 2003\end{array}$ & $?$ \\
\hline Arhysosage cactorum & $\begin{array}{l}\text { Gymnocalycium, Parodia } \\
\text { e Frailea (Cactaceae) }\end{array}$ & $\begin{array}{l}\text { Schlindwein and Oliveira } \\
\text { (unpubl data) }\end{array}$ & Yes \\
\hline Liphanthus sabulosos & & Mena and Ruz 2003 & Yes \\
\hline Calliopsis hondurasicus & $\begin{array}{l}\text { Aeschynomene americana } \\
\text { (Fabaceae) }\end{array}$ & Wcislo 1999 & Yes \\
\hline Callonychium petuniae & Petunia (Solanaceae) & Wittmann et al. 1990 & $?$ \\
\hline \multicolumn{4}{|l|}{ COLLETIDAE } \\
\hline Protodiscelis palpalis & $\begin{array}{l}\text { Hydrocleys martii } \\
\text { (Limnocharitaceae) }\end{array}$ & This study & $?$ \\
\hline \multicolumn{4}{|l|}{ HALICTIDAE } \\
\hline Systropha planidens & $\begin{array}{l}\text { Convolvulus } \\
\text { (Convolvulaceae) }\end{array}$ & Fraberger and Ayasse 2007 & Yes \\
\hline Systropha curvicornis & $\begin{array}{l}\text { Convolvulus } \\
\text { (Convolvulaceae) }\end{array}$ & Fraberger and Ayasse 2007 & Yes \\
\hline \multicolumn{4}{|l|}{ MEGACHILIDAE } \\
\hline Anthidium maculosum & Monarda austromontana & Alcock et al. $1977 \mathrm{a}$ & No \\
\hline Hoplitis anthocopoides & $\begin{array}{l}\text { Echium vulgare } \\
\text { (Boraginaceae) }\end{array}$ & Eickwort 1977 & Yes \\
\hline Ceblurgus longipalpis & $\begin{array}{l}\text { Cordia leucocephala } \\
\text { (Boraginaceae) }\end{array}$ & Pinheiro et al. 2008 & $?$ \\
\hline
\end{tabular}

\footnotetext{
${ }^{\text {a }}$ Males can also establish territories at nest sites
}

increase the defended area may increase defence costs, but bring no mating advantages.

\subsection{Territorial or wandering?}

Following the concept of economic defensibility proposed by Brown (1964), the defence of a resource involves costs and benefits, and territoriality will be enhanced only when this provides more benefits than an alternative behaviour. Considering (a) the high rate of invasions of territories, (b) the negative effect of agonistic contacts with competing males on the mating success of the territorial male and (c) the similar number of copulations of a territorial male to the invasive wandering males altogether, we ask if the territorial strategy is really adaptive in the studied population.

Taking into account the copulation rate of wandering males (24\%) divided per the average number of wandering males per invasion (1.98), we estimate that the rate of copulation of one non-territorial male in a territory is $12.2 \%$; i.e. three times lower than that of a territorial male. It was not possible to follow wandering males on their flight routes over the flowers of $H$. martii on the water bodies. However, because they are partitioned among territories, we 
suppose that wandering males must roam from one territory to another and face similar situations of competition with other territorial males on the whole surface of the water bodies.

The experimental presentation of mated females at the patrol sites shows that they lost sexual attractiveness soon after copulation. This rapid loss of female attractiveness could be associated with a male antiaphrodisiac pheromone passed to females during mating to render them less attractive to conspecific male. Males press the final metasomal segments on females during the copulas. The use of chemical compounds to prevent female re-mate has been previously found in Bombus terrestris (Baer et al. 2001), Osmia (Ayasse and Dutzler 1998) and Lasioglossum zephyrum (Kukuk 1985). In these bees, the application of the antiaphrodisiac imposes monandry. In $P$. palpalis, however, the reappearing attractiveness of females 1 day after copulation supposes a more complex mating system, which could be clarified with chemical analysis of female cuticle at different intervals after mate.

\subsection{Resource defence as mating strategy of males of oligolectic bees}

Emlen and Oring (1977) proposed that the spatial-temporal availability of the resource, including females, is one of the main forces that shape the evolution of male mating systems. Selection of female defence can be expected when nests, sources of receptive mates, are distributed in aggregated form, and defence of flowers when simultaneous access to clusters of females become unviable due to scattered distribution of nests.

For oligolectic bees with monandrous females that fly for only a short period of the year, there must be a strong selective advantage for behaviours that improve mate-locating and copulating efficiency of males. In oligolectic bees whose nests are sparsely distributed, the high costs to find virgins and the predictability of females' foraging sites should favour male mating systems based on flower resources. Resource defence has in fact evolved in unrelated taxa of oligolectic bees and, surprisingly, even in those in which females nest in aggregations (see examples in Table III). Unfortunately, nests of $P$. palpalis, as well as those of most species of the subfamily are not known. This is the first report on male mating strategies in Paracolletinae. A broad review on territoriality in males of solitary bees would provide interesting insights on the evolution of mating behaviour in bees.

\section{ACKNOWLEDGEMENTS}

We are grateful to Katja Hogendoorn and to the referees for critical comments which improved the manuscript. We thank Sérvio P. Ribeiro for improving the English and the Instituto Chico Mendes-ICMBio for providing work permission in the Estação Ecológica do Seridó. The authors were supported by Conselho Nacional de Desenvolvimento Científico e tecnológico (CNPq) and Deutscher Akademischer Austauschdienst (DAAD).

Territorial ou errant: quel comportement adoptent les mâles de Protodiscelis palpalis (Colletidae, Paracolletinae) dans leur recherche des femelles?

Comportement territorial / stratégie d'accouplement / oligolectie / abeille solitaire / Caatinga / Brésil

Territorialverhalten oder Wanderschaft: Das Verhalten der Männchen von Protodiscelis palpalis (Colletidae, Paracolletinae) auf der Suche nach Paarungspartnern.

Territorialität / Paarungstrategie / Oligolectie / solitäre Bienen / Caatinga

\section{REFERENCES}

Adams, E.S. (2001) Approaches to the study of territory size and shape. Annu. Rev. Ecol. Syst. 32, 277-303

Alcock, J. (1979) The behavioural consequences of size variation among males of the territorial wasp Hemipepsis ustulata (Hymenoptera: Pompilidae). Behaviour 71, 3-4

Alcock, J. (1996) Timing of mate-locating by males in relation to female activity in the carpenter bee Xylocopa varipuncta (Hymenoptera: Apidae). J. Insect Behav. 9, 321-328 
Alcock, J. (1997) Competition from large males and the alternative mating tactics of Dawson's burrowing bee, Amegilla dawsoni (Apidae, Apinae, Anthophorini). J. Insect Behav. 10, 99-113

Alcock, J. (2000) Possible causes of variation in territory tenure in a lekking pompilid wasp (Hemipepsis ustulata) (Hymenoptera). J. Insect Behav. 13, 439-453

Alcock, J., Jones, C.E., Buchmann, S.L. (1976) Location before emergence of the female bee, Centris pallida by its male (Hymenoptera, Anthophoridae). J. Zool. 179, 189-199

Alcock, J., Eickwort, G.C., Eickwort, K. (1977a) The reproductive behavior of Anthidium maculosum (Hymenoptera: Megachilidae) and the evolutionary significance of multiple copulations by females. Behav. Ecol. Sociobiol. 2, 385-396

Alcock, J., Jones, C.E., Buchmann, S.L. (1977b) Male mating strategies in the bee Centris pallida Fox (Anthophoridae: Hymenoptera). Am. Nat. 111, 146165

Almeida, E.A.B., Danforth, B.N. (2009) Phylogeny of colletid bees (Hymenoptera: Colletidae) inferred from four nuclear genes. Mol. Phylogenet. Evol. 50, 290-309

Alves dos Santos I. (2000) Notes on bees of the tribe Emphorini, Anais do IV Encontro sobre Abelhas, Ribeirão Preto, pp. 211-215

Andrade-Lima, D. (1961) Tipos de floresta de Pernambuco. Anais da Associação dos Geógrafos Brasileiros 2, 6985

Aubin-Horth, N., Dodson, J.J. (2004) Influence of individual body size and variable thresholds on the incidence of a sneaker male reproductive tactic in Atlantic salmon. Evolution 58, 136-144

Ayasse, M., Dutzler, G. (1998) The function of pheromones in the mating biology of Osmia bees (Hymenoptera: Megachilidae). Social Insects at the Turn of the Millenium, Proc. Int. Congr. IUSSI, 13th, p. 42. Flinders University Press, Adelaide, Australia

Baer, B., Morgan, E.D., Schmid-Hempel, P. (2001) An nonspecific fatty acid within the bumble-bee mating plug prevents females from remating. Proc. Natl. Acad. Sci. U. S. A 98, 3926-3928

Borgia, G. (1980) Sexual competition in Scatophaga stercoraria: size- and density-related changes in male ability to capture females. Behaviour 23, 185-206

Brockmann, H.J. (2001) An experimental approach to altering mating tactics in male horseshoe crabs (Limulus polyphemus). Behav. Ecol. 13, 232-238

Brown, J.L. (1964) The evolution of diversity in avian territorial systems. Wilson Bull. 76, 160-169

Butchart, S.H.M., Seddon, N., Ekstrom, J.M.M. (1999) Polyandry and competition for territories in bronzewinged jacanas. J. Anim. Ecol. 68, 928-939

Calsbeek, R., Marnocha, E. (2006) Context dependent territory defence: the importance of habitat structure in Anolis sagrei. Ethology 112, 537-543
Cane, J.H., Sipes, S. (2006) Characterizing floral specialization by bees: Analytical methods and revised lexicon for oligolecty. In: Waser, N.M., Ollerton, J. (eds.) Plan-pollination interactions: from specialization to generalization, pp. 99-122. The University of Chicago Press, Chicago

Carvalho, A.T., Schlindwein, C. (2011) Obligate association of an oligolectic bee and a seasonal aquatic herb in semi-arid north-eastern Brazil. Biol. J. Linn. Soc. 102, 355-368

Convey, P. (1989) Influences on the choice between territorial and satellite behavior in male Libellula quadrimaculata Linn. (Odonata: Libellulidae). Behaviour 1, 125-141

Cunha, R., Blochtein, B. (2003) Bionomia de Monoeca xanthopyga Harter-Marques, Cunha \& Moure (Hymenoptera, Apoidea, Tapinotaspidini) no Planalto das Araucárias, Rio Grande do Sul, Brasil. Rev. Bras. Zoologia 20, 107-113

Danforth, B.N. (1991) The morphology and behavior of dimorphic males in Perdita portalis (Hymenoptera: Andrenidae). Behav. Ecol. Sociobiol. 29, 235-247

Duque, J.G. (1973) O Nordeste e as lavouras xerófilas. Banco do Nordeste, Fortaleza

Eickwort, G.C. (1977) Male territorial behavior in the mason bee Hoplitis anthocopoides (Hymenoptera: Megachilidae). Anim. Behav. 25, 542-554

Eickwort, G.C., Ginsberg, H.S. (1980) Foraging and mating behavior in Apoidea. Annu. Rev. Entomol. 25, 421-446

Emlen, S.T., Oring, L.W. (1977) Ecology, sexual selection and the evolution of mating systems. Science 197, 215-223

Evans, H.E., O’Neill, K.M. (1978) Alternative mating strategies in the digger wasp Philanthus zebratus Cresson. Proc. Natl. Acad. Sci. U. S. A 75, 19011903

Fraberger, R.J., Ayasse, M. (2007) Mating behavior, male territoriality and chemical communication in the european spiral-horned bees, Systropha planidens and S. curvicornis (Hymenoptera: Halictidae). J. Kansas Entomol. Soc. 80, 348-360

Franck, D., Müller, A., Rogmann, N. (2003) A colour and size dimorphism in the green swordtail (population Jalapa): female mate choice, male-male competition, and male mating strategies. Acta Ethol. 5, 75-79

Hiller, B., Wittmann, D. (1994) Seasonality, nesting biology and mating behavior of the oil-collecting bee Epicharis dejeanii (Anthophoridae, Centridini). Biociências Porto Alegre 2, 107-124

Hugie, D.M., Lank, D.B. (1997) The resident's dilemma: a female choice model for the evolution of alternative mating strategies in lekking male ruffs (Philomachus pugnax). Behav. Ecol. 8, 218-225

Jennions, M.D., Backwell, P.R.Y. (1996) Residency and size affect fight duration and outcome in the 
fiddler crab Uca annulipes. Biol. J. Linn. Soc. 57, 293-306

Kukuk, P.F. (1985) Evidence for an antiaphrodisiac in the sweat bee Lasioglossum (Dialictus) zephyrum. Science 227, 656-657

Leys, R. (2000) Mate locating strategies of the green carpenter bees Xylocopa (Lestis) aeratus and X. (L.) bombylans. J. Zool. Lond. 252, 453-462

Medeiros, P.C.R., Schlindwein, C. (2003) Territórios de machos, acasalamento, distribuição e relação com plantas em Protomeliturga turnerae (Ducke, 1907) (Hymenoptera, Andrenidae). Rev. Bras. Entomol. 47, 589-596

Mena, P., Ruz, L. (2003) Field observations on the behaviour and nesting habits of Liphanthus sabulosus Reed (Hymenoptera: Andrenidae). J. Kansas Entomol. Soc. 76, 198-202

Michener, C.D. (2007) Bees of the World. The Johns Hopkins University Press, Baltimore

Milner, R.N.C., Booksmythe, I., Jennions, M.D., Backwell, P.R.Y. (2010) The battle of the sexes? Territory acquisition and defence in male and female fiddler crabs. Anim. Behav. 79(3), 735738

Murai, M. (1992) Courtship activity of wandering and burrow-holding male Uca arcuata. Ethology 92, 124-134

O’Neill, K.M. (1983) The significance of body size in territorial interactions of male beewolves (Hymenoptera: Sphecidae, Philanthus). Anim. Behav. 31, $404-411$

Oliveira, R., Schlindwein, C. (2010) Experimental demonstration of alternative mating tactics of males of Ptilothrix fructifera (Hymenoptera, Apidae). Anim. Behav. 80, 241-247

Paxton, R.J. (2005) Male mating behaviour and mating systems of bees: an overview. Apidologie 36, 145-156

Pinheiro, P.M., Carvalho, A.T., Oliveira, R., Schlindwein ,C. (2008) Machos de Ceblurgus longipalpis (Rophitinae: Halictidae) guardam alimento/recurso para copular, Anais do VIII Encontro sobre abelhas, Ribeirão Preto. [CD-ROOM]

Raw, A. (1976) The behavior of males of the solitary bee Osmia rufa (Megachilidae) searching for females. Behaviour 56, 279-285
Riechert, S.E. (1979) Games spiders play II. Resource assessment strategies. Behav. Ecol. Sociobiol. 6, $121-128$

Robertson, C. (1925) Heterotropic bees. Ecology 6, 412-436

Roubik, D.W. (1989) Ecology and natural history of tropical bees. Cambridge University Press, New York

Rutowski, R.L. (1991) The evolution of male mate-locating behavior in butterflies. Am. Nat. 138, 1121-1139

Sampaio, E.V.S.B. (1995) Overview of the Brazilian Caatinga. In: Bullock, S.H., Mooney, H.A., Medina, E. (eds.) Seasonally dry tropical forests, pp. 35-63. Cambridge University Press, Cambridge

Schlindwein, C. (2004) Are oligolectic bees always the most effective pollinators? In: Magalhães, F.B., Pereira, J.O.P. (eds.) Solitary bees-Conservation, rearing and management for pollination, pp. 231-240. Imprensa Universitária, UFC, Fortaleza

Silveira, F.A., Melo, G.A.R., Almeida, E.A.B. (2002) Abelhas brasileiras. Sistemática e identificação, Ed. IDMAR, Belo Horizonte

Simmons, L.W., Tomkins, J.L., Alcock, J. (2000) Can minor males of Dawson's burrowing bee, Amegilla dawsoni (Hymenoptera: Anthophorini) compensate for reduced access to virgin females through sperm competition? Behav. Ecol. 11, 319-325

Thiele, R., Inouye, B.D. (2007) Nesting biology, seasonality, and mating behavior of Epicharis metatarsalis (Hymenoptera: Apidae) in Northeastern Costa Rica. Ann. Entomol. Soc. Am. 100, 596-602

Thornhill, R., Alcock, J. (1983) The evolution of insect mating systems, 1st edn. Harvard University Press, Cambridge, Massachusetts

Utzed, C., Dell'anna, L. (1989) Wandering and territoriality in Libellula depressa L. (Anisoptera: Libellulidae). Adv. Odonatol. 4, 133-147

Wcislo, W.T. (1999) Male territoriality and nesting behavior of Calliopsis hondurasicus Cockerell (Hymenoptera: Andrenidae). J. Kansas Entomol. Soc. 72, 1-98

Wittmann, D., Radtke, R., Cure, J.R., Schifino-Wittmann, M.T. (1990) Coevolved reproductive strategies in the oligolectic bee Callonychium petuniae (Apoidea, Andrenidae) and three purple flowered Petunia species (Solanaceae) in southern Brazil. Z. Zool. Syst. Evolut-forsch. 28, 157-165 